\title{
3,4-Methylenedioxypyrovalerone: Neuropharmacological Impact of a Designer Stimulant of Abuse on Monoamine Transporters $\mathbf{s}$
}

\author{
Charlotte P. Magee, Christopher L. German, Yasmeen H. Siripathane, Peter S. Curtis, \\ David J. Anderson, Diana G. Wilkins, Glen R. Hanson, and Annette E. Fleckenstein \\ School of Dentistry (C.P.M., C.L.G., Y.H.S., P.S.C., G.R.H., A.E.F.), Interdepartmental Program in Neuroscience (C.P.M., C.L.G., \\ G.R.H., A.E.F.), Center for Human Toxicology (D.J.A., D.G.W.), and Department of Pathology (D.G.W.), University of Utah, Salt \\ Lake City, Utah
}

Received January 7, 2020; accepted May 5, 2020

\begin{abstract}
Methylenedioxypyrovalerone (MDPV) is an abused synthetic cathinone, commonly referred to as a "bath salt." Because the dopamine (DA) transporter (DAT) and vesicular monoamine transporter-2 (VMAT-2) are key regulators of both the abuse and neurotoxic potential of structurally and behaviorally related agents, the impact of MDPV on these transporters was investigated. Results revealed that a single in vivo MDPV administration rapidly (within 1 hour) and reversibly increased both rat striatal DAT and VMAT-2 activity, as assessed via $\left[{ }^{3} \mathrm{H}\right] \mathrm{DA}$ uptake in synaptosomes and synaptic vesicles, respectively, prepared from treated rats. There was no evidence of an MDPV-induced increase in plasmalemmal membrane DAT surface expression. Plasma concentrations of MDPV increased dose-dependently as assessed 1 hour after 2.5 and $5.0 \mathrm{mg} / \mathrm{kg}$ (s.c.) administration and returned to levels less than $10 \mathrm{ng} / \mathrm{ml}$ by 18 hours after $2.5 \mathrm{mg} / \mathrm{kg}$ (s.c.). Neither pretreatment with a D1 receptor (SCH23390), a D2 receptor (eticlopride), nor a nicotinic receptor (mecamylamine) antagonist attenuated the MDPV-induced increase in DAT activity. In contrast, eticlopride pretreatment attenuated both
\end{abstract}

the MDPV-induced increase in VMAT-2-mediated DA uptake and an associated increase in cytoplasmic-associated vesicle VMAT-2 immunoreactivity. SCH23390 did not attenuate the MDPV-induced increase in VMAT-2 activity. Repeated MDPV injections did not cause persistent DAergic deficits, as assessed 7 to 8 days later. The impact of MDPV on striatal and hippocampal serotonergic assessments was minimal. Taken together, these data contribute to a growing pharmacological rubric for evaluating the ever-growing list of designer cathinone-related stimulants. The profile of MDPV compared with related psychostimulants is discussed.

\section{SIGNIFICANCE STATEMENT}

Pharmacological characterization of the synthetic cathinone, 3,4-methylenedioxypyrovalerone (MDPV; commonly referred to as a "bath salt"), is critical for understanding the abuse liability and neurotoxic potential of this and related agents. Accordingly, the impact of MDPV on monoaminergic neurons is described and compared with that of related psychostimulants.

\section{Introduction}

3,4-Methylenedioxypyrovalerone (MDPV) is part of an expanding class of illicit psychostimulants, commonly referred to as "bath salts." Most of these "bath salts" are structural derivatives of the natural plant-derived product cathinone (Baumann et al., 2013). "Bath salts" can cause agitation, combative violent behavior, tachycardia, hallucinations, and death (Spiller et al., 2011). Approximately 1\% of high schoolage students use "bath salts," including MDPV, annually (Johnston et al., 2019).

MDPV has been described as a potent reuptake inhibitor at the dopamine (DA) transporter (DAT) [for review, see Baumann et al. (2017)]. In vitro, MDPV potently decreases

This work was supported by National Institute of Health National Institute on Drug Abuse [GrantR01 DA039145].

https://doi.org/10.1124/jpet.119.264895.

S This article has supplemental material available at jpet.aspetjournals.org.
DAT activity in rat synaptosomes with weaker activity at the serotonin transporter (SERT) (Baumann et al., 2013). In mouse striatal slices, DAT-mediated clearance is inhibited by MDPV as measured by fast-scan cyclic voltammetry (Baumann et al., 2013). Additionally, and consistent with other DAT reuptake inhibitors, MDPV is not a substrate for the transporter (Cameron et al., 2013) and does not evoke transporter-mediated release (Eshleman et al., 2013; Simmler et al., 2013).

Preclinical self-administration studies suggest that MDPV is reinforcing, as evidenced by escalating consumption when consumed orally (Gannon et al., 2017b) or administered intravenously (Aarde et al., 2013; Watterson et al., 2014; Schindler et al., 2016; Gannon et al., 2017a, 2018). MDPV selfadministration, like noncontingent MDPV administration, decreases reward threshold, indicative of reward potentiation; this effect likely involves cholinergic neurotransmission, as it is blocked by a nicotinic acetylcholine receptor $(\mathrm{nAChR})$

ABBREVIATIONS: DA, dopamine; DAT, dopamine transporter; DOPAC, dihydroxyphenylacetic acid; 5HIAA, 5-hydroxyindoleacetic acid; 5HT, 5hydroxytryptamine; KT, potassium tartrate; MDPV, 3,4-methylenedioxypyrovalerone; METH, methamphetamine hydrochloride; nACHr, nicotinic acetylcholine receptor; QCs, quality control samples; SCH23390, $R(+)$-7-chloro-8-hydroxy-3-methyl-1-phenyl-2,3,4,5-tetrahydro-1H-3-benzazepine hydrochloride; SERT, serotonin transporter; VMAT-2, vesicular monoamine transporter-2. 
antagonist (Geste et al., 2018). Of note, MDPV selfadministration induces locomotor hyperactivity while increasing extracellular DA levels in the nucleus accumbens, indicating that DA likely contributes prominently to the behavioral and reinforcing effects of MDPV (Schindler et al., 2016).

Two transporters primarily regulate the extracellular and intracellular distribution of DA: the plasmalemmal membrane DAT and the vesicular monoamine transporter-2 (VMAT-2). Many psychostimulants exert neurochemical and behavioral effects by altering DAT and VMAT-2 function. Furthermore, dysregulation of these transporters contributes to the amphetamine-related long-term deficits in central dopaminergic neuronal function. Of note, others and we have reported that the abuse of amphetamines is linked to development of basal ganglia and cerebellar disorders, including Parkinson's disease (Garwood et al., 2006; Callaghan et al., 2010, 2012; Christine et al., 2010; Curtin et al., 2015). Consequently, the primary purpose of the study was to investigate the impact of in vivo MDPV administration on DAT and VMAT-2 function and subcellular distribution.

Results elucidate the pharmacological profile of MDPV. First, despite directly decreasing DAT function in vitro, MDPV treatment rapidly and reversibly increases striatal DAT function, as assessed in striatal synaptosomes prepared from treated rats. Second, and although having little effect on VMAT-2 in vitro, in vivo MDPV administration rapidly and reversibly increases striatal VMAT-2 function, as assessed in non-membrane-associated (presumably cytoplasmic) vesicles prepared from treated rats. This effect involves an increase in cytoplasmic VMAT-2 immunoreactivity and is D2 receptormediated. Third, repeated MDPV injections (administered in a "binge-like" paradigm) cause neither persistent striatal nor hippocampal serotonergic or DAergic deficits. Taken together, these data contribute to an expanding literature assessing the pharmacologic and toxicologic properties of the ever-growing list of "bath salts" and may contribute to more efficient medical and legal management of these agents.

\section{Materials and Methods}

Reagents, Drugs, and Animals. All chemicals, unless otherwise specified, were purchased from Sigma Aldrich (St. Louis, MO). Male and female Sprague-Dawley rats (Charles River, Raleigh, NC; average weights between 350 and $450 \mathrm{~g}$ for males and $277 \mathrm{~g}$ for females) were housed in a temperature- $\left(22^{\circ} \mathrm{C}\right)$ and light-controlled (14/10 light/dark cycle) environment with food and water provided ad libitium. All experiments were performed in accordance with the National Institutes of Health Guidelines for the Care and Use of Laboratory Animals and approved by the University of Utah Institutional Animal Care and Use Committee. Ambient room temperature for animal handling and treatment was generally maintained at $23-24^{\circ} \mathrm{C}$. Core body temperatures were recorded using a rectal probe (RET-2; Physitemp, Clifton, $\mathrm{NJ})$, and rats were sacrificed via decapitation. ( \pm )-MDPV hydrochloride, ( \pm )-methamphetamine hydrochloride (METH), and cocaine hydrochloride were synthesized by Research Triangle Institute (Research Triangle Park, NC) and provided by the National Institute on Drug Abuse. MDPV and METH doses were calculated as respective free base; SCH23390 $(R(+)$-7-chloro-8-hydroxy-3-methyl-1-phenyl2,3,4,5-tetrahydro- $1 H$-3-benzazepine hydrochloride), eticlopride ( $S$-(-)-3-chloro-5-ethyl- $N$-[(1-ethyl-2-pyrrolidinyl)methyl]-6-hydroxy2-methoxybenzamide hydrochloride), and mecamylamine (N,2,3,3tetramethylbicyclo[2.2.1] heptan-2-amine hydrochloride) were calculated as salt. Sterile saline $(0.9 \% \mathrm{NaCl}, \mathrm{pH} 7.4)$ was used as the vehicle for all in vivo experiments.

Synaptosome Isolation. Two striata or two hippocampi were placed into $2 \mathrm{ml}$ of ice-cold sucrose buffer $(0.32 \mathrm{M}$ sucrose, $3.75 \mathrm{mM}$ $\mathrm{NaH}_{2} \mathrm{PO}_{4}, 12.7 \mathrm{mM} \mathrm{Na}_{2} \mathrm{HPO}_{4}$ ) and homogenized ( 20 strokes) by using a Dounce homogenizer. Samples were then centrifuged $(800 g$, 12 minutes, $\left.4^{\circ} \mathrm{C}\right)$. The resulting supernatant was centrifuged $\left(22,000 \mathrm{~g}, 15\right.$ minutes, $\left.4^{\circ} \mathrm{C}\right)$. For synaptosomal $\left[{ }^{3} \mathrm{H}\right] \mathrm{DA}$ uptake or $\left[{ }^{3} \mathrm{H}\right]$ 5 -hydroxytryptamine $\left(\left[{ }^{3} \mathrm{H}\right] 5 \mathrm{HT}\right)$ assays, the resulting whole synaptosomal pellets were resuspended in assay buffer $(126 \mathrm{mM} \mathrm{NaCl}$, $4.8 \mathrm{mM} \mathrm{KCl}, 1.3 \mathrm{mM} \mathrm{CaCl}_{2}, 1.4 \mathrm{mM} \mathrm{MgSO}_{4}, 11 \mathrm{mM}$ glucose, $1 \mathrm{mM}$ ascorbic acid, $3.75 \mathrm{mM} \mathrm{NaH} \mathrm{PO}_{4}, 12.7 \mathrm{mM} \mathrm{Na}_{2} \mathrm{HPO}_{4}$, pH 7.4). To minimize the possibility of residual drug introduced by the MDPV injection impacting results, synaptosomal pellets were washed by repeated centrifugation for all plasmalemmal $\left[{ }^{3} \mathrm{H}\right]$ monoamine uptake assays occurring within 18 hours of the MDPV treatment. Specifically, synaptosomal pellets were washed by centrifuging $(22,000 \mathrm{~g}$, 15 minutes, $4^{\circ} \mathrm{C}$ ) and resuspending in assay buffer; this process was repeated four times prior to the $\left[{ }^{3} \mathrm{H}\right]$ monoamine uptake assays. To remove residual MDPV from the synaptosomal preparation after in vitro MDPV preincubation, synaptosomal pellets were incubated with MDPV and washed by repeated centrifugation four or six times. Synaptosomal $\left[{ }^{3} \mathrm{H}\right]$ monoamine assays were conducted as described below.

Synaptosomal $\left[{ }^{3} \mathrm{H}\right] \mathrm{DA}$ and $\left[{ }^{3} \mathrm{H}\right] 5 \mathrm{HT}$ Uptake Assays. $\left[{ }^{3} \mathrm{H}\right]$ Monoamine uptake assays were performed on striatal or hippocampal crude synaptosomal pellets largely as described (Fleckenstein et al., 1997; Hadlock et al., 2009). Briefly, each assay tube contained synaptosomal tissue $\left(1.5 \mathrm{mg}\right.$ of tissue wet weight/ml for $\left[{ }^{3} \mathrm{H}\right] \mathrm{DA}$ uptake in the striatum, $7.5 \mathrm{mg}$ of tissue wet weight $/ \mathrm{ml}$ for $\left[{ }^{3} \mathrm{H}\right] 5 \mathrm{HT}$ uptake in the striatum, and $10.0 \mathrm{mg}$ tissue wet weight $/ \mathrm{ml}$ for $\left[{ }^{3} \mathrm{H}\right] 5 \mathrm{HT}$ uptake in the hippocampus) in assay buffer (126 mM NaCl, $4.8 \mathrm{mM} \mathrm{KCl}$, $1.3 \mathrm{mM} \mathrm{CaCl}_{2}, 1.4 \mathrm{mM} \mathrm{MgSO}_{4}, 11 \mathrm{mM}$ glucose, $1 \mathrm{mM}$ ascorbic acid, $3.75 \mathrm{mM} \mathrm{NaH}_{2} \mathrm{PO}_{4}, 12.7 \mathrm{mM} \mathrm{Na}_{2} \mathrm{HPO}_{4}, \mathrm{pH}$ 7.4) containing $1 \mu \mathrm{M}$ of pargyline. After preincubation of assay tubes for 10 minutes at $37^{\circ} \mathrm{C}$, assays were initiated by addition of $\left[{ }^{3} \mathrm{H}\right] \mathrm{DA}$ or $\left[{ }^{3} \mathrm{H}\right] 5 \mathrm{HT}(0.5$ or $5 \mathrm{nM}$ final concentrations, respectively). Samples were incubated at $37^{\circ} \mathrm{C}$ for 3 minutes and then filtered through Whatman GF/B filters (Whatman, Clifton, NJ) soaked previously in $0.05 \%$ polyethylenimine. Filters were washed rapidly three times with $5 \mathrm{ml}$ of ice-cold $0.32 \mathrm{M}$ sucrose using a Brandel filtering manifold. Radioactivity trapped in filters was counted by using a liquid scintillation counter and normalized to sample protein as determined by Bradford Protein Assay (Bio-Rad Protein Assay Dye Reagent Concentrate; Bio-Rad Laboratories, Hercules, CA).

Vesicular $\left[{ }^{3} \mathbf{H}\right]$ DA Uptake Assays. Synaptosomes from rat striatum were lysed by resuspension in ice-cold double-distilled $\mathrm{H}_{2} \mathrm{O}$, trituration with a 1-ml pipette, and homogenization with five strokes in a Dounce homogenizer. HEPES and potassium tartrate (KT) were then added (final concentration of 25 and $100 \mathrm{mM}$, respectively, $\mathrm{pH}$ 7.5). Samples were centrifuged (20,000g, 20 minutes, $4^{\circ} \mathrm{C}$ ) to remove synaptosomal membranes. The pellet (containing the synaptosomal membranes) was resuspended in assay buffer (final concentration: $100 \mathrm{mM} \mathrm{KT}, 25 \mathrm{mM}$ HEPES, $1.7 \mathrm{mM}$ ascorbic acid, $0.05 \mathrm{mM}$ EGTA, $0.01 \mathrm{mM}$ EDTA, $2 \mathrm{mM} \mathrm{MgSO}_{4}$; $\mathrm{pH}$ 7.5) and saved for use in Western blot. $\mathrm{MgSO}_{4}$ (1 mM final concentration) was added to the supernatant, which was centrifuged for $100,000 \mathrm{~g}$ for 45 minutes at $4^{\circ} \mathrm{C}$. The resulting pellet was resuspended in VMAT-2 assay buffer at a concentration of $50 \mathrm{mg} / \mathrm{ml}$ (original tissue wet weight) to obtain a vesicle-enriched (presumably cytoplasmic) preparation. Some sample was retained for Western blotting. For $\left[{ }^{3} \mathrm{H}\right] \mathrm{DA}$ uptake, synaptic vesicles were incubated in VMAT-2 assay buffer containing $2 \mathrm{mM}$ of ATP- $\mathrm{Mg}^{2+}$ and $30 \mathrm{nM}$ of $\left[{ }^{3} \mathrm{H}\right] \mathrm{DA}$ for 3 minutes $\left(30^{\circ} \mathrm{C}\right)$. Nonspecific $\left[{ }^{3} \mathrm{H}\right]$ DA uptake was defined by measuring $\left[{ }^{3} \mathrm{H}\right] \mathrm{DA}$ uptake in wash buffer (i.e., in the absence of ATP), with samples remaining on wet ice. After incubation, all samples were filtered through $0.5 \%$ polyethyleniminesoaked GF/F filter paper (Whatman) and washed three times with icecold VMAT-2 assay buffer. Radioactivity captured in filters was 
counted by using a liquid scintillation counter and normalized to sample protein as determined by Bradford protein assay.

Subcellular Fractionation for DAT Localization. Subcellular fractions were prepared as described by German et al. (2012). Briefly, striata were placed into $2 \mathrm{ml}$ of ice-cold $0.32 \mathrm{M}$ sucrose buffer $(0.32 \mathrm{M}$ sucrose, $3.75 \mathrm{mM} \mathrm{NaH}_{2} \mathrm{PO}_{4}, 12.7 \mathrm{mM} \mathrm{Na}_{2} \mathrm{HPO}_{4}$ ) containing protease and phosphatase inhibitors (final concentration: $1 \mathrm{mM}$ phenylmethylsulfonyl fluoride, $1.5 \mu \mathrm{M}$ aprotinin, $2.3 \mu \mathrm{M}$ leupeptin, $1 \mathrm{mM}$ sodium orthovanadate, $1 \mathrm{mM}$ sodium fluoride), and synaptosomes were obtained as described above. The synaptosomal pellet was resuspended in $450 \mu \mathrm{l}$ of ice-cold water. Then $50 \mu \mathrm{l}$ of buffer $(1 \mathrm{M} \mathrm{KT}, 0.25 \mathrm{M}$ HEPES) was added to stabilize solution. The lysate was centrifuged at $1500 \mathrm{~g}$ for 15 minutes at $4^{\circ} \mathrm{C}$. Protease and phosphatase inhibitors (final concentration: $1 \mathrm{mM}$ phenylmethylsulfonyl fluoride, $1.5 \mu \mathrm{M}$ aprotinin, $2.3 \mu \mathrm{M}$ leupeptin, $1 \mathrm{mM}$ sodium orthovanadate, $1 \mathrm{mM}$ sodium fluoride) were added to the supernatant (S3). The pellet (P3) was resuspended in RIPA Lysis Buffer (EMD Millipore Corp., Billerica, MD) containing protease and phosphatase inhibitors (final concentration: $1 \mathrm{mM}$ phenylmethylsulfonyl fluoride, $1.5 \mu \mathrm{M}$ aprotinin, $2.3 \mu \mathrm{M}$ leupeptin, $1 \mathrm{mM}$ sodium orthovanadate, $1 \mathrm{mM}$ sodium fluoride). The P3 and S3 fractions were analyzed via Western blot.

Subcellular Fractionation for VMAT-2 Localization. Striata were placed in $2 \mathrm{ml}$ of ice-cold $0.32 \mathrm{M}$ sucrose phosphate buffer, and synaptosomes were obtained as described above. Synaptosomes were lysed in ice-cold water at a concentration of $75 \mathrm{mg} / \mathrm{ml}$ tissue wet weight. The lysate was centrifuged at $22,000 \mathrm{~g}$ for 20 minutes at $4^{\circ} \mathrm{C}$. The resulting supernatant was the non-membrane-associated fraction. The resulting pellet was resuspended in ice-cold water at a concentration of $75 \mathrm{mg} / \mathrm{ml}$ tissue wet weight and was the membrane-associated fraction. The non-membrane- and membraneassociated fractions were analyzed via Western blot.

Western Blotting. Samples (for DAT localization: $5 \mu \mathrm{g}$ of protein from P3 and $10 \mu \mathrm{g}$ of protein from S3; for VMAT-2 localization: $20 \mu \mathrm{l}$ of the non-membrane-associated fraction containing 9-12 $\mu \mathrm{g}$ protein, $20.5 \mu \mathrm{l}$ of the membrane-associated fraction containing $12-18 \mu \mathrm{g}$ protein, and $1 \mu \mathrm{g}$ protein for the vesicle-enriched fraction) were mixed with lithium dodecyl sulfate sample buffer (Bolt LDS Sample Buffer; ThermoFisher Scientific, Rockford, IL) and dithiothreitol (50 mM) and heated at $70^{\circ} \mathrm{C}$ for 10 minutes. Samples were then loaded onto Bolt 4\%-12\% Bis-Tris Plus Gels (ThermoFisher Scientific) and electrophoresed for 1-1.5 hours ( $200 \mathrm{~V}$ constant). Samples were transferred to polyvinylidene difluoride membranes (Perkin Elmer, Waltham, MA) for 2-2.5 hours (35 V constant). Membranes were blocked with StartingBlock T20 (ThermoFisher Scientific) for 20-30 minutes and then probed with primary antibody overnight $\left(4^{\circ} \mathrm{C}\right)$. The DAT primary antibody was produced by Sigma Genosys (Sigma Aldrich) raised against N-terminal amino acids 42-59 (1:1000) (Vaughan, 1995). The VMAT-2 primary antibody was produced by Bethyl Laboratories and raised against a 20-amino acid c-terminal sequence of human VMAT2 (1:2000). After primary antibody incubation, membranes were then probed with secondary antibody [Peroxidase AffiniPure Goat AntiRabbit; Jackson Immunoresearch Laboratories (1:10,000)] for 1 hour with gentle agitation at room temperature. Membranes were developed by using SuperSignal West Pico PLUS (ThermoFisher Scientific) and imaged with an Alpha Innotech FluorChem HD2 imager. Band density was determined using the FluorChem software and quantification. Protein levels were determined by Bradford assay or by Pierce BCA Protein Assay (ThermoFisher Scientific).

For Fig. 3, data were normalized to sample protein concentrations.

High-Performance Liquid Chromatography. One striatum or hippocampus from each treated rat was flash frozen on dry ice immediately after decapitation and was stored at $-80^{\circ} \mathrm{C}$ until assay. On the day of assay, tissues were thawed and sonicated for 3-5 seconds at a concentration of $20 \mathrm{mg}$ striata/ml or $25 \mathrm{mg}$ hippocampus/ ml wet weight in tissue buffer $(50 \mathrm{mM}$ sodium phosphate, $30 \mathrm{mM}$ citric acid, $\mathrm{pH}=2.5$, containing $10 \%$ methanol $)$ and centrifuged $(30,000 \mathrm{~g}$, 1 hour). The resulting pellet was sonicated in $2 \mathrm{ml}$ of tissue buffer and assayed for protein by Bradford assay. For hippocampal analysis,
$40 \mu \mathrm{l}$ of the resulting supernatant was injected onto a C-18 reversephase analytical column (Partisphere, 5 - $\mu \mathrm{m}$ spheres; $250 \times 4.6 \mathrm{~mm}$; Whatman). For striatal analysis, supernatant was further diluted to $5 \mathrm{mg} / \mathrm{ml}$ original wet weight in tissue buffer, and $12 \mu \mathrm{l}$ was injected onto a C-18 reverse-phase analytical column (Partisphere, 5- $\mu \mathrm{m}$ spheres; $250 \times 4.6 \mathrm{~mm}$; Whatman). DA, dihydroxyphenylacetic acid (DOPAC), norepinephrine, 5HT, and 5-hydroxyindoleacetic acid (5HIAA) content was determined by using an amperometric electrochemical detector with a flow cell using a three-electrode configuration (2465 Electrochemical Detector; Waters, Milford, MA). The glassy carbon working electrode potential was set at $+0.70 \mathrm{~V}$ relative to a saltbridge $\mathrm{Ag}^{+} / \mathrm{AgCl}$ reference electrode. The mobile phase consisted of $0.05 \mathrm{M}$ sodium phosphate, $0.03 \mathrm{M}$ citrate buffer containing $0.12 \mathrm{mM}$ EDTA, $0.032 \%$ sodium octyl sulfate, and $20 \%$ methanol $(\mathrm{pH}=2.8)$. Monoamine and metabolite content were determined by comparing sample peak areas with those recorded from standards run on the same day (recorded by Waters Breeze 2 HPLC system).

MDPV Assessment Utilizing Basified Liquid/Liquid Extraction Followed by Ultra-High-Performance Liquid ChromatographyElectrospray Ionization-Tandem Mass Spectrometry. Trunk blood was collected into a 4.5-ml collection tube with gel and lithium heparin on ice (BD Vacutainer, Franklin Lakes, NJ). Blood samples were centrifuged at $3,000 \mathrm{~g}$ for 15 minutes at $4^{\circ} \mathrm{C}$ to obtain plasma. The rat plasma sample aliquot volume was $0.1 \mathrm{ml}$, and MDPV-d8 was added as the internal standard ( $50 \mu \mathrm{l}$ of a $200-\mathrm{ng} / \mathrm{ml}$ working solution). Reference materials for MDPV and the internal standard were obtained from Cerilliant (Round Rock, TX). Prior to extraction, the $\mathrm{pH}$ of the rat plasma was adjusted by addition of $0.5 \mathrm{ml}$ of $10 \%(\mathrm{v} / \mathrm{v})$ ammonium hydroxide (Fisher Chemical, Fair Lawn, NJ), and the samples were extracted with 1-chlorobutane (OmniSolv; EMD Millipore). The organic layer was isolated and evaporated to dryness, and the extract was reconstituted in mobile phase for analysis by ultra-high-performance liquid chromatography-electrospray ionization-tandem mass spectrometry. The liquid chromatographic system was a Waters Acquity UPLC autosampler and pumping system. Chromatographic separation was performed on a Phenomenex (Torrance, CA) Luna Omega C18 column $(2.1 \times 50 \mathrm{~mm}, 1.6-\mu \mathrm{m}$ particle size $)$ by using gradient elution with a cycle time of approximately 6 minutes per injection. The mobile phases were $5 \mathrm{mM}$ ammonium acetate and methanol (Honeywell Burdick \& Jackson, Muskegon, MI). The mass spectrometer was a Waters Quattro Premier XE triple quadrupole mass spectrometer that was operated in the selected reaction monitoring mode under positive ionization conditions. For MDPV and MDPV-d8, the selected reaction monitoring transitions were mass/charge 276.2-126.1 and mass/charge 284.2-134.1, respectively. The concentration of MDPV in the samples was determined from the ratio of the peak area of MDPV to the peak area of MDPV-d8 and comparison of this ratio with the calibration curve that was generated from the analysis of rat plasma fortified with known concentrations of MDPV and the internal standard.

Duplicate calibrators were prepared fresh for each analytical run in rat plasma at nominal concentrations for MDPV of 10, 25, 50, 100, 250, 500,750 , and $1000 \mathrm{ng} / \mathrm{ml}$. Two double blanks (matrix without internal standard) and two zero samples (matrix with internal standard) were prepared for each analytical batch with the same lot of rat plasma used for the calibrators. Quality control samples (QCs) were prepared in advance at nominal concentrations for MDPV of 30,150 , and $700 \mathrm{ng} / \mathrm{ml}$. Aliquots of the QCs were placed into polypropylene tubes and stored at $-80^{\circ} \mathrm{C}$ until thawing for analysis in triplicate with each analytical run of study samples.

For the analysis of samples in synaptosomal matrix, the following modifications were made to the rat plasma method. Duplicate calibrators were prepared fresh for each analytical run in rat plasma to conserve synaptosomal matrix at nominal concentrations for MDPV of $0.25,0.5,1,5,10,40,80$, and $100 \mathrm{ng} / \mathrm{ml}$. QCs were prepared by 10 -fold dilution of the higher concentration range rat plasma $\mathrm{QCs}$ at nominal concentrations for MDPV of 3,15 , and $70 \mathrm{ng} / \mathrm{ml}$ and analyzed in triplicate for each analytical run. In addition, QCs in synaptosomal matrix at concentrations for MDPV of 3 and $70 \mathrm{ng} / \mathrm{ml}$ were prepared for each analytical run for analysis in triplicate. Finally, the volume of 
mobile phase used for reconstitution and the mass spectrometer tuning parameters were optimized for the reduced concentration range.

Food Training and Self-Administration. Food training and self-administration was accomplished by using an operant chamber ( $30.5 \mathrm{~cm} \times 25.5 \mathrm{~cm} \times 30.5 \mathrm{~cm}$; Coulbourn Instruments, Whitehall, PA) in a room maintained at $26.9 \pm 0.7^{\circ} \mathrm{C}$ as described previously (McFadden et al., 2012). Prior to surgery, each rat was trained to press for a 45-mg food pellet on a fixed-ratio schedule of reinforcement during four 14-hour overnight sessions. During these sessions, the active lever was counterbalanced across rats and alternated each session such that each lever was reinforced for two training sessions. After food training, rats were anesthetized, and an indwelling catheter was implanted. The catheter was constructed as described previously (Frankel et al., 2011). Each rat received Prevail (flunixin meglumine; $1.1 \mathrm{mg} / \mathrm{kg}$, s.c.) on the day of and after the surgery. Immediately after surgery and daily thereafter until self-administration, each rat was infused with $0.1 \mathrm{ml}$ of cefazolin $(10 \mathrm{mg} / \mathrm{ml})$. The animals' food was reduced to $25 \mathrm{~g}$ the day before self-administration began. On all following days, animals were free-fed.

Rats underwent 7 days of self-administration (90 minutes/session; FR1; $0.0175 \mathrm{mg} /$ infusion MDPV or $10 \mu \mathrm{l}$ saline during the light cycle). For each active lever press, an infusion pump connected to a liquid swivel (Coulbourn Instruments) delivered $10 \mu \mathrm{l}$ of MDPV or saline per infusion over a 5 -second duration through a polyethylene tube located within a spring leash (Coulbourn Instruments) tethered to the rat. During this period, both levers were retracted. After the infusion, the levers remained retracted for an additional 20 seconds. The active lever was counterbalanced within each group. Pressing the inactive lever resulted in no programmed consequences. MDPV self-administering rats were included in analysis if they 1 ) pressed an average of more than 10 active lever presses per day, and 2) the ratio of active/inactive lever presses was $\geq 2: 1$ (Brennan et al., 2010). Core body temperatures were collected at the end of the last self-administration session.

Statistical Analysis. All samples within a given experiment were processed concurrently unless stated otherwise. Statistical analysis was conducted in GraphPad Prism 7 (San Diego, CA). Statistical outliers were identified using a Grubb's test (i.e., extreme studentized deviate method) and excluded from analysis. Statistical analyses between two groups were conducted by using a $t$-test. Analyses among more than two groups were conducted by using a one- or two-way ANOVA (with repeated measures if appropriate) followed by Bonferroni post hoc analyses. In cases requiring a nonparametric test because of significantly different variance among groups, a Mann Whitney test was conducted in place of a $t$-test, and a Kruskal-Wallis test followed by Dunn's multiple comparisons test was conducted in place of a one-way ANOVA. Data are expressed as means \pm S.E.M.

\section{Results}

MDPV Self-Administration. Results presented in Fig. 1 demonstrate that MDPV $(0.0175 \mathrm{mg} / 10 \mu \mathrm{l}$ infusion; 90 -minute daily sessions for 7 days) is readily self-administered by male Sprague-Dawley rats. Rats discriminated between the active and inactive levers at a ratio of at least 2:1 beginning on the 3rd day. Core body temperatures, as assessed within 30 minutes of the final self-administration session, did not differ between MDPV- and saline-administering groups (saline, $38.8 \pm 0.2^{\circ} \mathrm{C} ; \mathrm{MDPV}, 38.9 \pm 0.2^{\circ} \mathrm{C}, n=5$ /group; $\mathrm{t}_{8}=0.367$, $P=0.724)$. Cumulative MDPV intake over the course of the seven sessions ranged from 2.10 to $6.56 \mathrm{mg}$ (mean $=3.72 \pm$ $0.75, n=5$ (group). MDPV plasma concentrations ranged from 20.9 to $79.5 \mathrm{ng} / \mathrm{ml}($ mean $=50.1 \pm 10.3)$, as assessed 1 hour after the final self-administration session.

Effects of In Vivo Exposure to MDPV on VMAT-2. Results presented in Fig. 2A demonstrate that in vivo administration of $\operatorname{MDPV}\left(2.5-5.0 \mathrm{mg} / \mathrm{kg}\right.$, s.c.) increased vesicular $\left[{ }^{3} \mathrm{H}\right] \mathrm{DA}$ uptake,

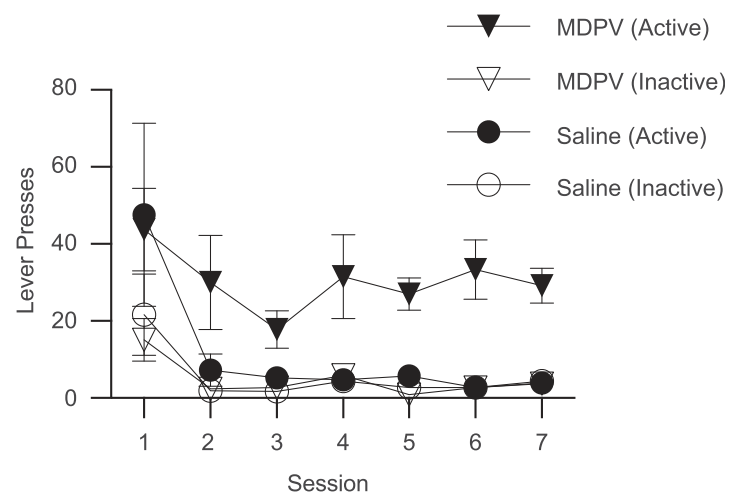

Fig. 1. MDPV is self-administered by male Sprague-Dawley rats. Rats self-administered MDPV (0.0175 mg/infusion; FR1; $n=5)$ or saline $(10 \mu \mathrm{l} /$ infusion; $n=5$ ) for 7 days (90 minutes/day). Values represent means, and vertical lines represent 1 S.E.M.

as assessed in the striatal vesicle-enriched preparation from male rats 1 hour after injection $\left[\mathrm{F}_{2,18}=27.75, P<0.0001\right.$; post hoc comparison indicated significant differences between 0 and $2.5 \mathrm{mg} / \mathrm{kg}$ and between 0 and $5.0 \mathrm{mg} / \mathrm{kg}(P<0.0001)]$. The increase in VMAT-2 function caused by $2.5 \mathrm{mg} / \mathrm{kg}$ (s.c.) was reversed 6 hours later [Fig. 2B; Kruskal-Wallis statistic $=15.43$, $P=0.0039$; post hoc comparison reveals differences between 0 and 1 hour $(P<0.005)$ and between 0 and 3 hours $(P<0.05)$ ].

Results presented in Fig. 3 demonstrate that MDPV $(2.5 \mathrm{mg} / \mathrm{kg}$, s.c.) concurrently increased and decreased striatal VMAT-2 immunoreactivity in the non-membrane-associated fraction $\left(\mathrm{t}_{14}=2.382, P=0.032\right)$ and the membrane-associated fraction $\left(\mathrm{t}_{14}=2.198, P=0.045\right)$ prepared from male rats, respectively, compared with saline $(1 \mathrm{ml} / \mathrm{kg}$, s.c.) vehicle controls, as assessed 1 hour after treatment. Western blots display band localization, and the associated graphs represent band density per microgram protein.

Results presented in Fig. 4A demonstrate that a single administration of the D1 antagonist, SCH-23390 $(0.5 \mathrm{mg} / \mathrm{kg}$, i.p.), 15 minutes prior to $\mathrm{MDPV}$ ( $2.5 \mathrm{mg} / \mathrm{kg}$, s.c.) or saline $\left(1 \mathrm{ml} / \mathrm{kg}\right.$, s.c.) was without effect on $\left[{ }^{3} \mathrm{H}\right] \mathrm{DA}$ uptake (MDPV main effect: $\mathrm{F}_{1,20}=26.37, P<0.0001 ; \mathrm{SCH}-23390$ main effect: $\mathrm{F}_{1,20}=4.017, P=0.059$; interaction: $\mathrm{F}_{1,20}=0.498, P=0.489$ ). In contrast, results presented in Fig. $4 \mathrm{~B}$ demonstrate that a single administration of the D2 antagonist, eticlopride ( $0.5 \mathrm{mg} / \mathrm{kg}$ i.p.), 15 minutes prior to MDPV ( $2.5 \mathrm{mg} / \mathrm{kg}$, s.c.) or saline $(1 \mathrm{ml} / \mathrm{kg}$, s.c. $)$ attenuated the MDPV-induced increase in striatal vesicular $\left[{ }^{3} \mathrm{H}\right] \mathrm{DA}$ uptake in male rats, as assessed 1 hour after MDPV or saline treatment (MDPV main effect: $\mathrm{F}_{1,26}=33.95, P<0.0001 ;$ eticlopride main effect: $\mathrm{F}_{1,26}=5.235$, $P=0.031$; interaction $\left.\mathrm{F}_{1,26}=10.95, P=0.0028\right)$. Additionally, this same eticlopride pretreatment (a single administration $0.5 \mathrm{mg} / \mathrm{kg}$, i.p., 15 minutes prior to a single administration of MDPV $2.5 \mathrm{mg} / \mathrm{kg}$, s.c.) also attenuated the MDPV-induced redistribution of VMAT-2 (Fig. 4C; MDPV main effect: $\mathrm{F}_{1,26}=$ 15.34, $P<0.0006$; eticlopride main effect: $\mathrm{F}_{1,26}=6.916, P=$ 0.014; interaction: $\mathrm{F}_{1,26}=12.33, P=0.002$ ).

Effects of In Vivo Exposure to MDPV on DAT. In vivo administration of MDPV ( $2.5 \mathrm{mg} / \mathrm{kg}$, s.c.) rapidly and reversibly increased striatal $\left[{ }^{3} \mathrm{H}\right] \mathrm{DA}$ uptake, as assessed in striatal synaptosomes prepared from male rats (Fig. $5 ; \mathrm{F}_{4,33}=3.098$, $P=0.0286$; post hoc comparisons indicate significant increase at 1 hour, $P=0.0275$ ). No alterations in DAT localization between the subcellular fractions, $\mathrm{P} 3\left(\mathrm{t}_{14}=0.208, P=0.838\right)$ and 


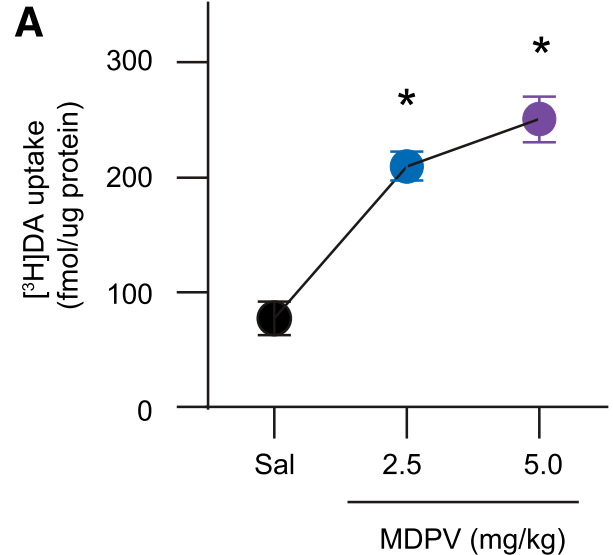

B

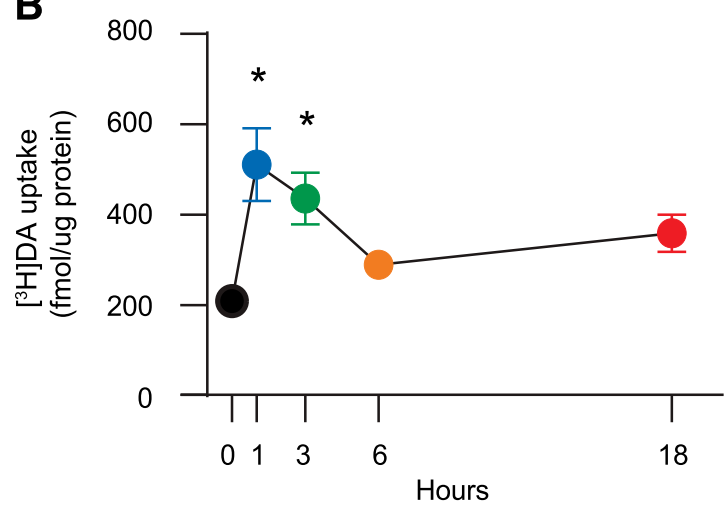

Fig. 2. MDPV administration rapidly and reversibly increases striatal vesicular $\left[{ }^{3} \mathrm{H}\right] \mathrm{DA}$ uptake. (A) Rats received a single injection (s.c.) of MDPV $(2.5$ or $5.0 \mathrm{mg} / \mathrm{kg})$ or saline vehicle $(1 \mathrm{ml} / \mathrm{kg})$ and were sacrificed 1 hour later. Values/columns represent means, and vertical lines represent 1 S.E.M. $(n=6-8)$. (B) Rats received a single injection (s.c.) of MDPV $(2.5 \mathrm{mg} / \mathrm{kg})$ or saline $(1 \mathrm{ml} / \mathrm{kg}$; zero-time value) and were sacrificed 1-18 hours later. Values/columns represent means, and vertical lines represent 1 S.E.M. from two combined independent experiments $(n=11-14)$. ${ }^{*} P<$ 0.05 from saline.

S3 (Mann Whitney $\mathrm{U}=21.5, P=0.291, n=8$ /group), were detected 1 hour after MDPV treatment (2.5 mg/kg, s.c.; Fig. 6).

The MDPV-induced increase in DAT activity was not attenuated by pretreatment with a single administration of either the D1 antagonist, SCH23390 (0.5 mg/kg, i.p.; Fig. 7A; MDPV main effect: $\mathrm{F}_{1,28}=75.29, P<0.0001$; SCH23390 main effect: $\mathrm{F}_{1,28}=1.242, P=0.275$; interaction: $\mathrm{F}_{1,28}=0.233, P=$ $0.633)$, or the D2 antagonist, eticlopride $(0.5 \mathrm{mg} / \mathrm{kg}$, i.p.; Fig. 7B; MDPV main effect: $\mathrm{F}_{1,22}=41.67, P<0.0001$; eticlopride main effect: $\mathrm{F}_{1,22}=0.100, P=0.756$; interaction: $\mathrm{F}_{1,28}=1.904, P=$ $0.182)$, administered 15 minutes prior to $\mathrm{MDPV}(2.5 \mathrm{mg} / \mathrm{kg}$, s.c.). Of note, pretreatment with the D1 antagonist SCH23390 prevented the MDPV-induced increase in temperature (saline/ saline $=38.0 \pm 0.1^{\circ} \mathrm{C}$, saline/MDPV $=38.7 \pm 0.2^{\circ} \mathrm{C}, \mathrm{SCH} 23390 /$ saline $=38.2 \pm 0.1^{\circ} \mathrm{C}, \mathrm{SCH} / \mathrm{MDPV}=38.1 \pm 0.2^{\circ} \mathrm{C}$ ).

Although studies have demonstrated that $\mathrm{nAChR}$ blockade attenuates some behavioral effects of MDPV (Geste et al., 2018), the MDPV-induced increase in DAT activity was not attenuated by pretreatment with a single administration of the nonselective $\mathrm{nAChR}$ antagonist mecamylamine $(3 \mathrm{mg} / \mathrm{kg}$, s.c.) administered 10 minutes prior to $\mathrm{MDPV}(2.5 \mathrm{mg} / \mathrm{kg}$, s.c.; Fig. 7C; MDPV main effect: $\mathrm{F}_{1,27}=53.77, P<0.0001$; mecamylamine main effect: $\mathrm{F}_{1,27}=1.468, P=0.236$; interaction: $\left.\mathrm{F}_{1,27}=1.668, P=0.208\right)$.
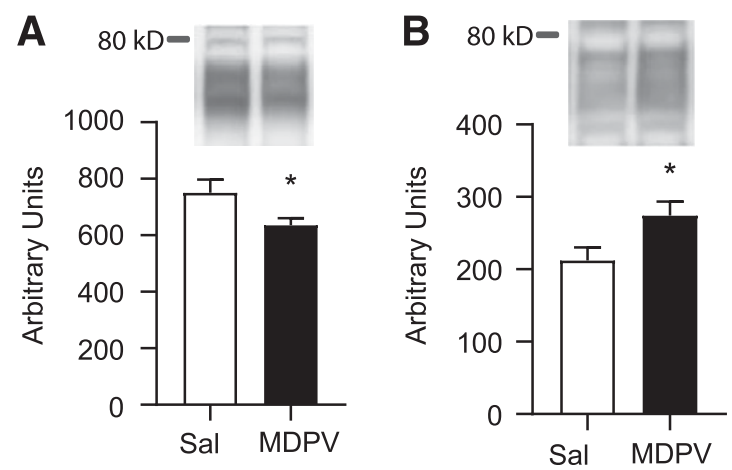

Fig. 3. VMAT-2 immunoreactivity decreases in the (A) membraneassociated fraction and increases in the (B) non-membrane-associated fraction in rats that received a single injection (s.c.) of MDPV $(2.5 \mathrm{mg} / \mathrm{kg})$ compared with rats that received a single injection (s.c.) of saline $(1 \mathrm{ml} / \mathrm{kg})$ and were sacrificed 1 hour later. Western blots display band localization prior to normalization to protein content. Bar graphs represent data normalized to protein content (see Materials and Methods). Columns represent means, and vertical lines represent 1 S.E.M. $(n=8) . * P<0.05$ from saline.

Effects of In Vivo MDPV Administration on Monoamine Content. Despite concurrent alterations in VMAT-2 and DAT function, results presented in Table 1 demonstrate that MDPV (2.5 or $5.0 \mathrm{mg} / \mathrm{kg}$, s.c.) had no effect on content of striatal DA $\left(\mathrm{F}_{2,21}=2.85, P=0.080\right)$ and modestly increased content of the DA metabolite, DOPAC $\left(\mathrm{F}_{2,21}=6.678, P=\right.$ 0.006), as assessed 1 hour after treatment. Post hoc comparisons reveal that compared with saline treated rats, DOPAC is increased in rats that received $2.5(P<0.01)$ or $5.0 \mathrm{mg} / \mathrm{kg}(P<$ 0.05) MDPV.

In contrast to effects on DAT, in vivo administration of $\operatorname{MDPV}(0.5,2.5$, or $5.0 \mathrm{mg} / \mathrm{kg}$, s.c.) was without effect on plasmalemmal $\left[{ }^{3} \mathrm{H}\right] 5 \mathrm{HT}$ uptake in the striatum or the hippocampus of male rats, as assessed 1 hour after administration (Supplemental Table 1). Furthermore, in vivo administration of MDPV (2.5 or $5.0 \mathrm{mg} / \mathrm{kg}$, s.c.) was without effect on norepinephrine, 5HIAA, or 5HT in the hippocampus at this 1-hour time point (Supplemental Table 2).

Effects of MDPV on Core Body Temperature. A single 2.5 or $5.0 \mathrm{mg} / \mathrm{kg}$ injection (s.c.) of MDPV increased core body temperatures in male rats compared with saline controls $\left(1 \mathrm{ml} / \mathrm{kg}\right.$ ) (saline, $37.4 \pm 0.2^{\circ} \mathrm{C}$; MDPV $2.5 \mathrm{mg} / \mathrm{kg}, 39.2 \pm 0.3^{\circ}$ $\mathrm{C}$; MDPV $5.0 \mathrm{mg} / \mathrm{kg}, 38.6 \pm 0.2^{\circ} \mathrm{C}$ ), as assessed 30 minutes after a single administration $\left(\mathrm{F}_{2,21}=15.62, P<0.0001\right.$; post hoc comparison revealed differences between 0 and $2.5 \mathrm{mg} / \mathrm{kg}$ and between 0 and $5.0 \mathrm{mg} / \mathrm{kg} ; P<0.0001$ ). The effect on core body temperature was reversible, as temperatures returned to baseline 2.5 hours after a single $2.5 \mathrm{mg} / \mathrm{kg}$ (s.c.) injection (saline $=37.6 \pm 0.1^{\circ} \mathrm{C}, 30$ minutes $=38.5 \pm 0.2^{\circ} \mathrm{C}^{*}, 2.5$ hours $=$ $38.1 \pm 0.1^{\circ} \mathrm{C}, 5.5$ hours $=37.5 \pm 0.2^{\circ} \mathrm{C}, 17.5$ hours $=37.0 \pm 0.2^{\circ}$ $\mathrm{C} ; \mathrm{F}_{4,33}=10.39, P<0.0001 ; *$ indicates significant difference from saline, $P=0.008$ ).

MDPV Pharmacokinetics. Plasma concentrations of MDPV, as assessed 1 hour after administration of 2.5 and $5.0 \mathrm{mg} / \mathrm{kg}$ (s.c.) in male rats, were $367 \pm 22$ and $823 \pm 56 \mathrm{ng} /$ $\mathrm{ml}$, respectively. Pharmacokinetic analysis 1, 3, 6, and 18 hours after administration of $2.5 \mathrm{mg} / \mathrm{kg}$ (s.c.) reveals that plasma MDPV concentrations declined sharply after 1 hour and were below the lower limit of quantification of $10 \mathrm{ng} / \mathrm{ml}$ in eight out of nine samples by 18 hours ( 1 hour, $325 \pm 28 \mathrm{ng} / \mathrm{ml}$; 3 hours, $80.4 \pm 11.9 \mathrm{ng} / \mathrm{ml}$; 6 hours, $13.1 \pm 3.3 \mathrm{ng} / \mathrm{ml})$. 


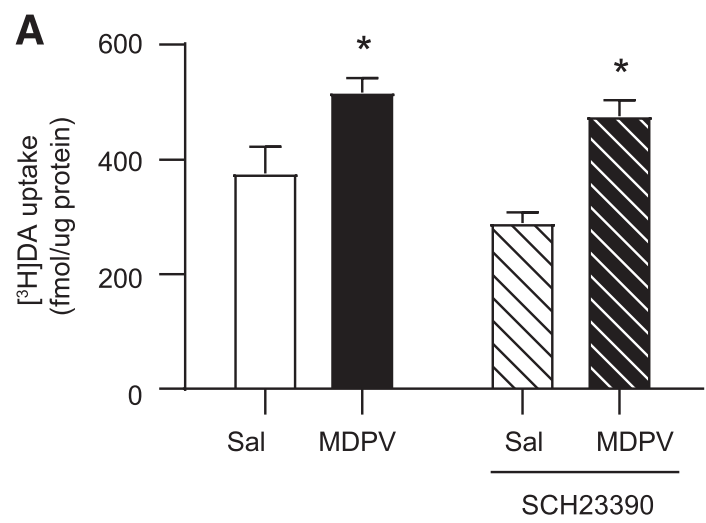

B
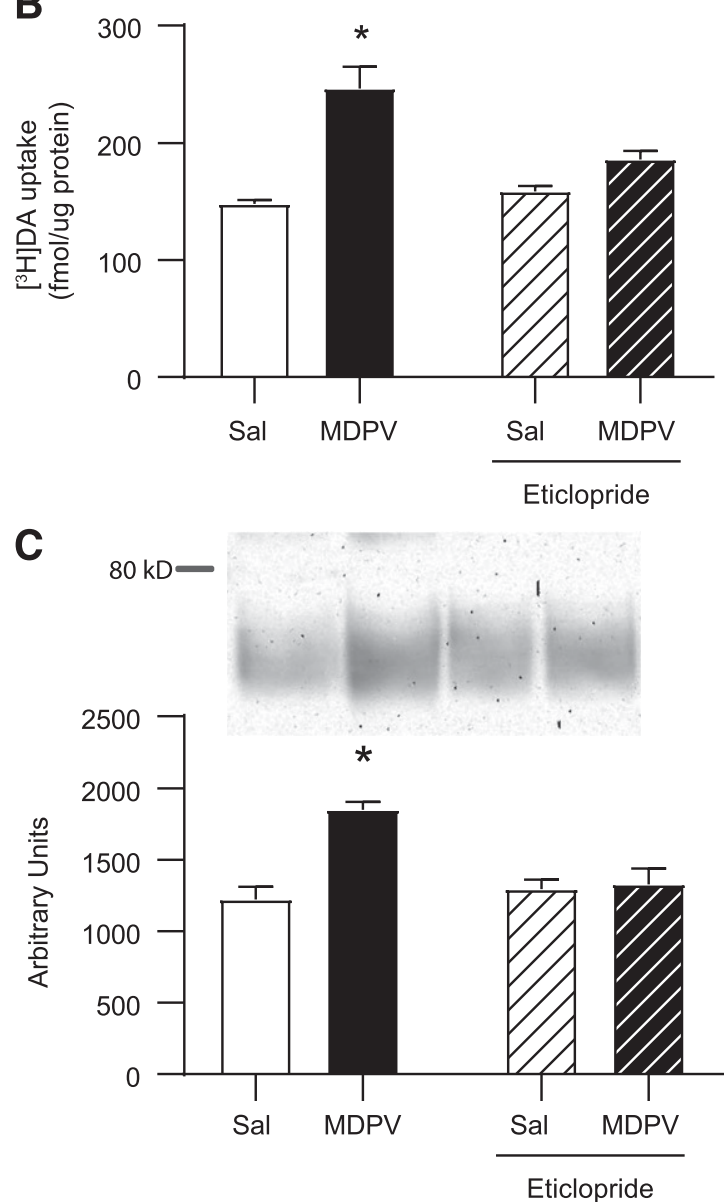

Fig. 4. D1 receptor antagonist pretreatment is without effect on the MDPV-induced increase in striatal vesicular $\left[{ }^{3} \mathrm{H}\right] \mathrm{DA}$ uptake, whereas D2 receptor antagonist pretreatment attenuates the MDPV-induced increases in striatal vesicular $\left[{ }^{3} \mathrm{H}\right] \mathrm{DA}$ uptake and associated VMAT-2 redistribution. Rats received a single intraperitoneal injection of (A) $\mathrm{SCH} 23390(0.5 \mathrm{mg} / \mathrm{kg})$ and $(\mathrm{B}$ and $\mathrm{C})$ eticlopride $(0.5 \mathrm{mg} / \mathrm{kg})$ or saline $(1 \mathrm{ml} / \mathrm{kg})$, followed by a single injection (s.c.) of MDPV $(2.5 \mathrm{mg} / \mathrm{kg})$ or saline $(1 \mathrm{ml} / \mathrm{kg}) 15$ minutes later. Rats were sacrificed 1 hour after second injection. (A) $\left[{ }^{3} \mathrm{H}\right] \mathrm{DA}$ uptake, (B) $\left[{ }^{3} \mathrm{H}\right] \mathrm{DA}$ uptake, and (C) representative Western blot of VMAT-2 immunoreactivity in the vesicle-enriched fraction as described in Materials and Methods and associated quantification. Columns represent means, and vertical lines represent 1 S.E.M. $(n=6-8)$. $* P<0.05$ from saline.

Impact In Vivo of Repeated MDPV Administrations on Monoaminergic Neurons. Results presented in Fig. 8 demonstrate that despite causing moderate hyperthermia (Fig. $8 \mathrm{~B}$; drug $\times$ time interaction $\mathrm{F}=14.56, P<0.0001$ ), and

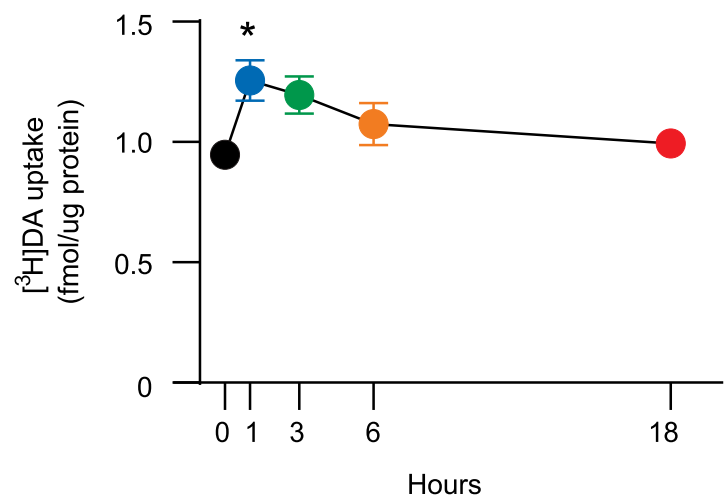

Fig. 5. MDPV administration rapidly and reversibly increases striatal plasmalemmal $\left[{ }^{3} \mathrm{H}\right] \mathrm{DA}$ uptake. Rats received a single injection (s.c.) of MDPV $(2.5 \mathrm{mg} / \mathrm{kg})$ or saline $(1 \mathrm{ml} / \mathrm{kg}$; zero-time value) and were sacrificed 1-18 hours later. Symbols represent means, and vertical lines represent 1 S.E.M. $(n=7$ to 8$)$. ${ }^{*} P<0.05$ from saline.

in contrast to METH (three injections, 2-hour intervals, $7.5 \mathrm{mg} / \mathrm{kg}$ per injection), repeated administrations of MDPV (three injections, 2-hour intervals, 2.5 or $5.0 \mathrm{mg} / \mathrm{kg}$ per injection) did not alter $\left[{ }^{3} \mathrm{H}\right] \mathrm{DA}$ uptake in male rats as assessed 7 days after treatment (Fig. 8A; $\mathrm{F}_{3,48}=4.642, P=0.0063$; post hoc comparisons revealed no differences between saline- and MDPV-treated animals, $P>0.05$ ) and decreased $\left[{ }^{3} \mathrm{H}\right] \mathrm{DA}$ uptake in METHtreated rats compared with saline-treated rats $(P<0.01)$. This finding was extended to female rats. Specifically, repeated MDPV administrations (three injections, 2-hour intervals, 2.5 or $5.0 \mathrm{mg} / \mathrm{kg}$ per injection) did not alter $\left[{ }^{3} \mathrm{H}\right] \mathrm{DA}$ uptake in the striatum as assessed 8 days after treatment $(3 \times 0 \mathrm{mg} / \mathrm{kg} \mathrm{MDPV}$, $3.31 \pm 0.16 \mathrm{fmol}\left[{ }^{3} \mathrm{H}\right] \mathrm{DA} / \mu \mathrm{g}$ protein; $3 \times 2.5 \mathrm{mg} / \mathrm{kg} \mathrm{MDPV}, 2.94 \pm$ $0.15 \mathrm{fmol}\left[{ }^{3} \mathrm{H}\right] \mathrm{DA} / \mu \mathrm{g}$ protein; $3 \times 5.0 \mathrm{mg} / \mathrm{kg} \mathrm{MDPV}=3.31 \pm 0.21$ fmol $\left[{ }^{3} \mathrm{H}\right] \mathrm{DA} / \mu \mathrm{g}$ protein; $\mathrm{F}_{2,18}=1.771, P=0.199$ ).

Repeated MDPV administrations (three injections, 2-hour intervals, 2.5 or $5.0 \mathrm{mg} / \mathrm{kg}$ ) did not affect plasmalemmal striatal or hippocampal $\left[{ }^{3} \mathrm{H}\right] 5 \mathrm{HT}$ uptake, as assessed 8 days after MDPV treatment (Supplemental Table 3). In the hippocampus, repeated administrations of MDPV did not affect norepinephrine, 5HIAA, or 5HT content (Supplemental Table 4).

IC $_{50}$ of MDPV on VMAT-2 and DAT. Direct in vitro application of MDPV at concentrations as large as $10 \mu \mathrm{M}$ was without effect on vesicular $\left[{ }^{3} \mathrm{H}\right] \mathrm{DA}$ uptake as assessed in a vesicle-enriched (presumably cytoplasmic) subcellular fraction prepared from male rat striata (data not shown). Direct application of MDPV ( 3 minutes, $37^{\circ} \mathrm{C}$, as described in Materials and Methods in Synaptosomal $\left[{ }^{3} \mathrm{H}\right] \mathrm{DA}$ and $\left[{ }^{3} \mathrm{H}\right]$ $5 H T$ Uptake Assays) inhibited striatal plasmalemmal $\left[{ }^{3} \mathrm{H}\right] \mathrm{DA}$ uptake with an $\mathrm{IC}_{50}$ of $5.4 \pm 0.9 \mathrm{nM}$.

Effects of 1-Hour In Vitro Incubation with MDPV on DAT. Similar to direct application of MDPV for 3 minutes, incubation of synaptosomes with MDPV for 1 hour decreased $\left[{ }^{3} \mathrm{H}\right] \mathrm{DA}$ uptake (data not shown). In contrast to the direct effects of MDPV on DAT, Table 2 demonstrates this direct decrease induced by MDPV incubation was no longer observed when synaptosomes were "washed" four to six times (see Materials and Methods; four washes: $\mathrm{F}_{3,20}=0.840, P=0.488$; six washes: $\left.\mathrm{F}_{3,20}=0.959, P=0.427\right)$. Resulting MDPV concentrations at the time of the $\left[{ }^{3} \mathrm{H}\right] \mathrm{DA}$ uptake assay, all of which at least one order of magnitude less than the $\mathrm{IC}_{50}$ of $5.4 \mathrm{nM}$, are reported in Table 2. 


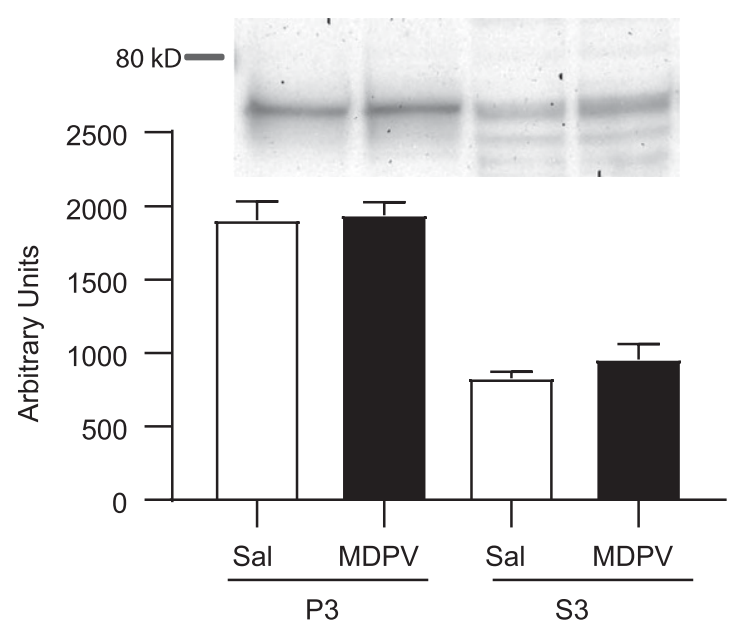

Fig. 6. MDPV administration does not affect DAT localization in synaptosome subcellular fractions. Representative image of Western blots as described in Materials and Methods, and quantification of DAT in P3 and S3 obtained from rats that received a single injection (s.c.) of MDPV $(2.5 \mathrm{mg} / \mathrm{kg})$ or saline $(1 \mathrm{ml} / \mathrm{kg})$ and were sacrificed 1 hour later. Values represent means, and vertical lines represent 1 S.E.M. $(n=8)$.

\section{Discussion}

As demonstrated previously, MDPV is readily selfadministered by male rats (Aarde et al., 2013, 2015a,b; Watterson et al., 2014; Schindler et al., 2016; Gannon et al., 2017a; Geste et al., 2018). The present study extends these findings by reporting that plasma MDPV concentrations 1 hour after the final self-administration session range from 20.9 to $79.5 \mathrm{ng} / \mathrm{ml}$. In contrast, concentrations found 1 hour after $2.5 \mathrm{mg} / \mathrm{kg}$ (s.c; 367 and $325 \mathrm{ng} / \mathrm{ml}$ ) were approximately sevenfold greater. The latter results are consistent with circulating drug concentrations reported after a single administration of MDPV (0.5-2.0 mg/kg, s.c.) (Anizan et al., 2016). These levels resemble plasma concentrations in human MDPV abusers (i.e., 24-241 ng/ml; Spiller et al., 2011), with the important caveat of interspecies differences in drug metabolism. The average "bath salts" dose in human abusers ranges from 5 to $20 \mathrm{mg}$ (Ross et al., 2012), and the dose primarily used in this study $(2.5 \mathrm{mg} / \mathrm{kg})$ is equivalent to a 24 $\mathrm{mg}$ dose in a 60-kg human (Reagan-Shaw et al., 2008).

A second novel finding described herein is that MDPV administration rapidly and reversibly increases VMAT-2 function, as assessed in a non-membrane-associated (presumably cytoplasmic) subcellular fraction. This effect is associated with increases and decreases in levels of nonmembrane-associated and plasmalemmal membrane-associated VMAT-2, respectively. We hypothesize that this shift represents a rapid redistribution of VMAT-2, and presumably associated vesicles, within striatal nerve terminals. Of note, D2 antagonist (eticlopride) pretreatment attenuated both the increase in cytoplasmic $\left[{ }^{3} \mathrm{H}\right] \mathrm{DA}$ uptake and VMAT-2 immunoreactivity. In contrast, D1 antagonist (SCH23390) pretreatment did not attenuate the MDPV-induced increase in $\left[{ }^{3} \mathrm{H}\right] \mathrm{DA}$ uptake.

Findings of concurrently increased VMAT-2 function and VMAT-2 immunoreactivity in a cytoplasmic subcellular fraction are consistent with the rapid in vivo effects of several "classical" DA reuptake inhibitors. For example, cocaine and methylphenidate redistribute VMAT-2 (and presumably associated vesicles) from a synaptosomal membrane-associated
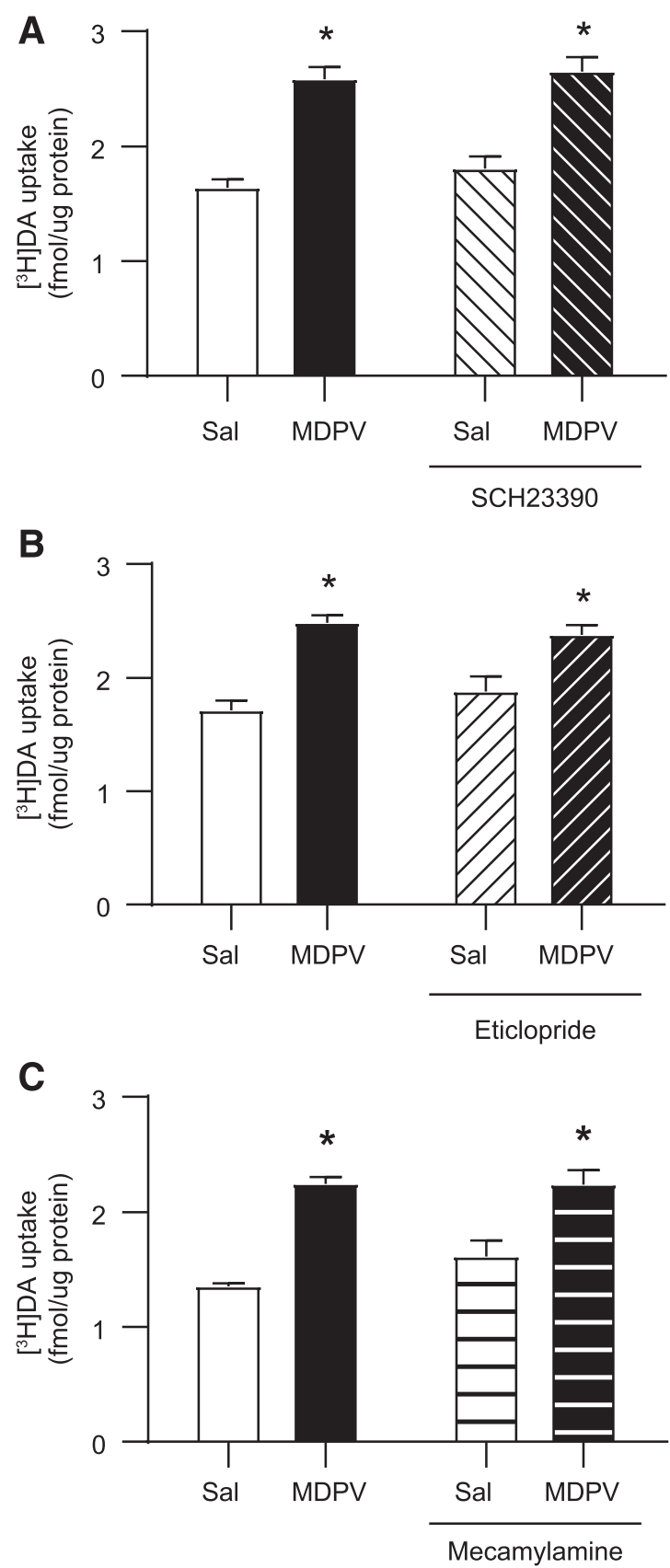

Fig. 7. Neither D1, D2, nor nACh receptor antagonist pretreatment attenuates the MDPV-induced increase in striatal plasmalemmal $\left[{ }^{3} \mathrm{H}\right] \mathrm{DA}$ uptake. Rats received a single injection of (A) SCH23390 ( $0.5 \mathrm{mg} / \mathrm{kg}$, i.p.) or saline ( $1 \mathrm{ml} / \mathrm{kg}$, i.p.), (B) eticlopride $(0.5 \mathrm{mg} / \mathrm{kg}$, i.p.) or saline $(1 \mathrm{ml} / \mathrm{kg}$, i.p.), or (C) mecamylamine $(3 \mathrm{mg} / \mathrm{kg}$, s.c.) or saline $(1 \mathrm{ml} / \mathrm{kg}$, s.c.) followed by a single injection (s.c.) of MDPV $(2.5 \mathrm{mg} / \mathrm{kg}$ ) or saline vehicle $(1 \mathrm{ml} / \mathrm{kg}) 15$ or 10 minutes later for SCH23390/eticlopride or mecamylamine, respectively. Rats were sacrificed 1 hour after the second injection. Columns represent means, and vertical lines represent 1 S.E.M. $(n=8) . * P<0.05$ from respective saline control.

fraction to a cytoplasmic fraction. Furthermore, and similar to cocaine (Farnsworth et al., 2009) and methylphenidate (Volz et al., 2008), eticlopride pretreatment prevents the MDPVinduced increase in VMAT-2 activity. Of note, these VMAT-2 data stand in contrast to drugs classically referred to as DA "releasing agents" such as METH. For example, METH redistributes VMAT-2 to a subcellular neuronal fraction that is not retained in the preparation of synaptosomes (Riddle et al., 2002). 
TABLE 1

In vivo MDPV administration increases striatal DOPAC concentrations without effect on striatal DA concentrations $1 \mathrm{~h}$ after administration

Rats received a single injection (s.c.) of MDPV $(2.5$ or $5.0 \mathrm{mg} / \mathrm{kg}$ ) or saline vehicle $(1 \mathrm{ml} / \mathrm{kg})$ and were sacrificed $1 \mathrm{~h}$ later. Values represent means \pm S.E.M. $(n=8)$.

\begin{tabular}{lcc}
\hline Drug Treatment & DA (ng/mg protein) & DOPAC $(\mathrm{ng} / \mathrm{mg}$ protein) \\
\hline Saline $1 \mathrm{ml} / \mathrm{kg}$ & $134.9 \pm 6.7$ & $26.81 \pm 1.2$ \\
$2.5 \mathrm{mg} / \mathrm{kg} \mathrm{MDPV}$ & $149.2 \pm 7.3$ & $32.47 \pm 1.5^{*}$ \\
$5.0 \mathrm{mg} / \mathrm{kg} \mathrm{MDPV}$ & $129.0 \pm 3.8$ & $32.35 \pm 1.0^{*}$ \\
\hline
\end{tabular}

${ }^{*} P<0.05$ from saline.

Activation of D2 autoreceptors by extracellular DA may be key to the MDPV-induced redistribution of VMAT-2 (Truong et al., 2004).

The impact of MDPV administration on striatal DAT was also investigated. There is one report of rapid DAT upregulation after MDPV exposure, and it was suggested it may be because of increased DAT cell surface expression (as determined by $\left[{ }^{3} \mathrm{H}\right]$ WIN 35428 binding to differentiated PC12 cells) (Lopez-Arnau et al., 2019). In contrast, another report indicated that MDPV causes rapid internalization (albeit after incubation of human embryonic kidney cells) as well as a decreased total striatal DAT and altered subcellular localization 24 hours after in vivo administration (Colon-Perez et al., 2018). Our results confirmed findings by Lopez-Arnau et al. (2019) that MDPV rapidly and reversibly increased DAT function, as assessed in synaptosomes prepared from treated rats. However, and in contrast to both Lopez-Arnau et al. (2019) and Colon-Perez et al. (2018), we did not find evidence of altered DAT surface expression.

Reports of rapid increases in DAT function after in vivo stimulant administration are sparse. Cocaine treatment reportedly increases DAT function, as assessed ex vivo in synaptosomes prepared from treated rats (Fleckenstein et al., 1999; Daws et al., 2002; Lopez-Arnau et al., 2019) and in vivo (Daws et al., 2002). Thus, and although studies noted above demonstrate that MDPV acts via a cocaine-like mechanism (Baumann et al., 2013), additional studies are needed to investigate a potential dual action of these stimulants, that is, one to inhibit and a second to enhance DAT function.

To further investigate the impact of MDPV on DAT, in vitro studies were conducted wherein striatal synaptosomes from naïve rats were preincubated for 1 hour with MDPV in vitro. In some experiments, the uptake assays were conducted directly after the preincubation (i.e., synaptosomes were not "washed"), and results revealed a decrease in $\left[{ }^{3} \mathrm{H}\right] \mathrm{DA}$ uptake, consistent with other reuptake inhibitors. In separate studies, synaptosomes were "washed" four to six times prior to assessment of $\left[{ }^{3} \mathrm{H}\right] \mathrm{DA}$ uptake owing to discussion by LopezArnau et al. (2019) regarding the "high affinity of MDPV for DAT which is probably accompanied by a very slow dissociation rate." The resulting MDPV concentrations in these latter studies at the time of $\left[{ }^{3} \mathrm{H}\right] \mathrm{DA}$ uptake were evaluated and were all at least one order of magnitude less than the $\mathrm{IC}_{50}$ of $5.4 \mathrm{nM}$ (i.e., as reported in Table 2). Furthermore, in these latter studies, MDPV incubation did not alter DAT activity. These data stand in contrast to Lopez-Arnau et al. (2019), who reported that in vitro incubation with MDPV at concentrations of $1 \mu \mathrm{M}$ increased $\left[{ }^{3} \mathrm{H}\right] \mathrm{DA}$ uptake, albeit by using concentrations of the transmitter (i.e., $200 \mathrm{nM}$ ) that were 400-fold greater than concentrations used in the present studies (i.e., $0.5 \mathrm{nM}$ ).
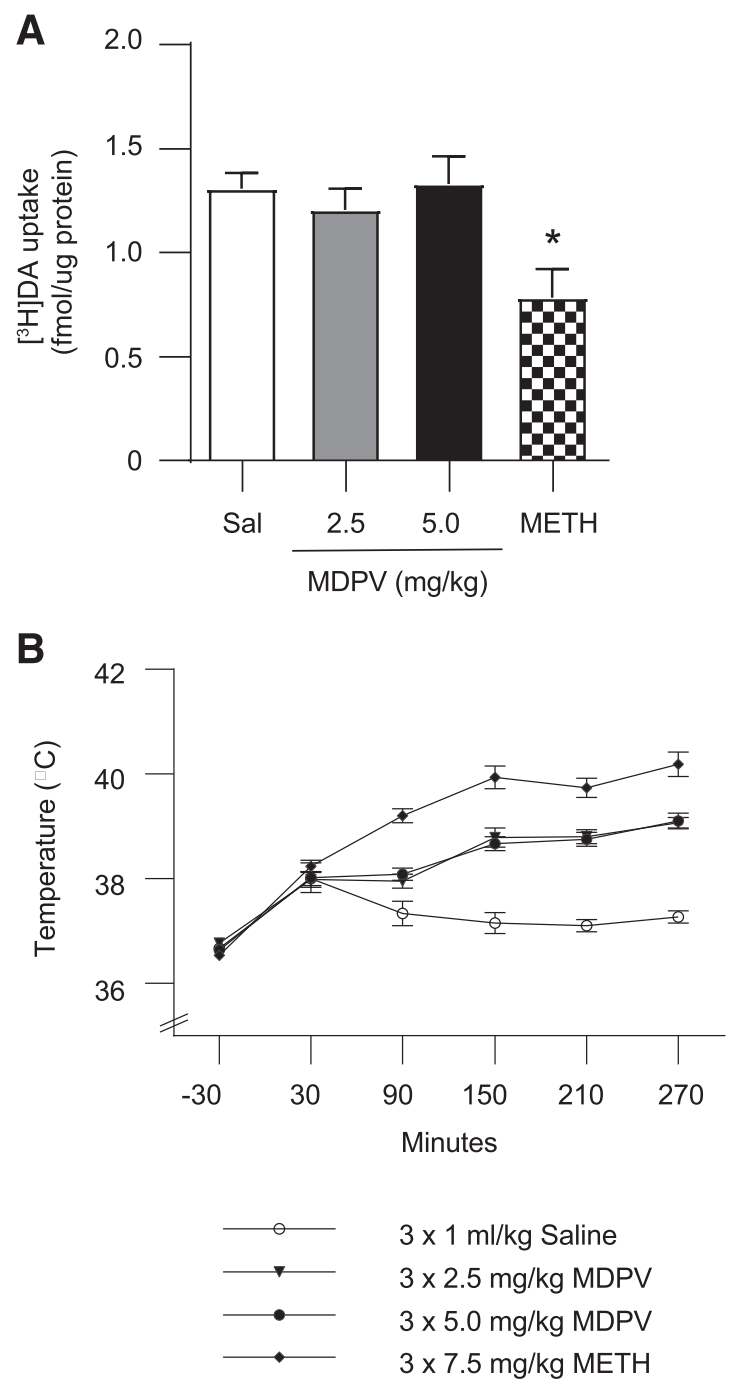

Fig. 8. MDPV, unlike METH, does not alter plasmalemmal $\left[{ }^{3} \mathrm{H}\right] \mathrm{DA}$ uptake as assessed 7 days after treatment, despite causing hyperthermia. Male rats received multiple injections (s.c.; 2-hour intervals) of either MDPV $(3 \times 2.5$ or $5.0 \mathrm{mg} / \mathrm{kg} /$ injection $)$ or saline vehicle $(3 \times 1 \mathrm{ml} / \mathrm{kg}$ per injection). (A) $\left[{ }^{3} \mathrm{H}\right] \mathrm{DA}$ uptake as assessed 7 days after MDPV treatment. (B) Core body temperatures were assessed at times indicated by arrows. Values/columns represent means, and vertical lines represent 1 S.E.M. $(n=11-14)$.

Our in vitro incubation data confirm that effects of psychostimulants on DAT in vitro do not always mimic effects after in vivo exposure (German et al., 2012). One explanation for a lack of in vitro effect is that neuronal circuitry beyond that present in the synaptosomal preparation may be required to reveal the in vivo MDPV-induced increase in plasmalemmal $\left[{ }^{3} \mathrm{H}\right] \mathrm{DA}$ uptake. Thus, because D2 receptor activation can regulate DAT function (Dickinson et al., 1999; Bolan et al., 2007), the impact of eticlopride pretreatment was investigated. Results revealed that eticlopride did not attenuate the MDPV-induced increase in DAT function. Although we cannot rule out the possibility that the dose and/or timing of eticlopride administration may not have been optimal, we observed eticlopride-mediated blockade of MDPV-induced stereotypy and locomotion (data not shown). Of note, this eticlopride dose and timing was selected because it attenuates or prevents DAT inhibitor- or stimulant-induced alterations in VMAT-2 function (Brown et al., 2001; Sandoval et al., 2002; 
TABLE 2

In vitro preincubation of striatal synaptosomes with MDPV is without effect on plasmalemmal $\left[{ }^{3} \mathrm{H}\right] \mathrm{DA}$ uptake

Synaptosomes were preincubated with varying concentrations of MDPV $(0-1000 \mathrm{nM})$ for $1 \mathrm{~h}$ at $37^{\circ} \mathrm{C}$. Samples were then centrifuged $\left(22,000 \mathrm{~g}\right.$ for $15 \mathrm{~min}$ at $\left.4^{\circ} \mathrm{C}\right)$ and resuspended in assay buffer either four or six times and then assayed for $\left[{ }^{3} \mathrm{H}\right] \mathrm{DA}$ uptake as described in the Materials and Methods. MDPV concentrations represent the drug concentration at the time of $\left[{ }^{3} \mathrm{H}\right] \mathrm{DA}$ uptake assay. Values represent means \pm S.E.M. $(n=6)$.

\begin{tabular}{lrcc}
\hline $\begin{array}{c}\text { Number of } \\
\text { "Washes" }\end{array}$ & $\begin{array}{c}\text { MDPV } \\
\text { Preincubation } \\
(\mathrm{nM})\end{array}$ & $\begin{array}{c}{\left[{ }^{3} \mathrm{H}\right] \mathrm{DA} \text { Uptake }} \\
(\mathrm{fmol} / \mu \mathrm{g} \text { protein })\end{array}$ & $\begin{array}{c}\text { MDPV in Synaptosome } \\
\text { Preparation after } \\
\text { Repeated Washing }(\mathrm{nM})\end{array}$ \\
\hline Four & 0 & $1.74 \pm 0.09$ & 0 \\
& 10 & $1.95 \pm 0.13$ & 0 \\
& 100 & $1.92 \pm 0.13$ & $0.20 \pm 0.11$ \\
Six & 1000 & $1.96 \pm 0.10$ & $0.26 \pm 0.11$ \\
& 0 & $1.27 \pm 0.06$ & 0 \\
& 10 & $1.34 \pm 0.07$ & 0 \\
& 100 & $1.25 \pm 0.06$ & $0.02 \pm 0.18$ \\
& 1000 & $1.39 \pm 0.05$ & $0.09 \pm 0.18$ \\
\hline
\end{tabular}

Truong et al., 2004; Rau et al., 2005), including the MDPVinduced increase in VMAT-2 function reported in the present manuscript. Similarly, pretreatment with SCH23390 did not attenuate the MDPV-induced increase in DAT function.

Because treatment with the nAChR antagonist, mecamylamine, reduced MDPV self-administration and blocked the reward-enhancing effects of MDPV (Geste et al., 2018), the role of nAChRs in the effects of MDPV on DAT function was assessed. Results revealed that mecamylamine had no effect on the MDPV-induced increase in DAT activity. Thus, given these and the DA antagonist data, the subcellular mechanism underlying the impact of MDPV on DAT function remains to be elucidated.

Given that there is an upregulation in DA transport and sequestration by DAT and VMAT-2, respectively, DA and DOPAC tissue content were analyzed. Results revealed that despite the concurrent MDPV-induced increases in DAT and VMAT-2 function, tissue DA content is not altered, as assessed 1 hour after treatment. In contrast, a modest increase in DOPAC was noted, which may suggest an increase in DA turnover/altered metabolism as suggested by Colon-Perez et al. (2018).

Of interest are findings that MDPV can increase vesicular DA release (Hoffman et al., 2016). Future studies as to how these data, coupled with alterations in DAT/VMAT-2 function, along with alterations in DA turnover/metabolism, are warranted.

To determine if the MDPV-induced transporter upregulation extended to other monoamine transporters, we examined SERT function after an in vivo MDPV administration. Upregulation of plasmalemmal transporters was specific to DAT, as MDPV did not increase SERT function in either the striatum or hippocampus, nor did it alter norepinephrine, 5HIAA, or 5HT content in the hippocampus.

Synthetic cathinone users often will repeatedly selfadminister within a single drug-taking session to prevent the "come-down" associated with a single administration (Ross et al., 2012). To model this pattern and assess the long-term impacts of MDPV, rats were exposed to a "binge" regimen and evaluated 7 to 8 days later. Results revealed that repeated MDPV administrations (three injections, 2.5 or $5.0 \mathrm{mg} / \mathrm{kg} /$ injection, 2-hour intervals) to rats (male or female) did not cause persistent deficits in striatal $\left[{ }^{3} \mathrm{H}\right] \mathrm{DA}$ or striatal $\left[{ }^{3} \mathrm{H}\right] 5 \mathrm{HT}$ uptake. These data are consistent with another report involving female mice of limited to no dopaminergic deficits 48 hours after MDPV treatment (Anneken et al., 2015).

It is interesting to speculate that enhanced VMAT-2 capacity may contribute to the lack of persistent DAergic deficits caused by MDPV. Specifically, the increase in DAT activity may promote DA uptake into the cytoplasmic space, where it would otherwise be rapidly converted to reactive DA quinones and related species were it not for the capacity of MDPV to rapidly sequester DA owing to enhanced vesicular DA uptake.

In summary, MDPV has a pharmacological profile that in some ways resembles other reuptake inhibitors, such as methylphenidate or cocaine, but also causes an upregulation in DAT function. The effects of MDPV on both DAT and VMAT-2 likely contribute to its highly reinforcing properties while also mitigating persistent dopaminergic deficits because of aberrant DA transport.

\section{Authorship Contributions}

Participated in research design: Magee, German, Wilkins, Fleckenstein.

Conducted experiments: Magee, German, Siripathane, Curtis, Anderson, Fleckenstein.

Performed data analysis: Magee, Wilkins, Fleckenstein.

Wrote or contributed to the writing of the manuscript: Magee, German, Anderson, Wilkins, Hanson, Fleckenstein.

\section{References}

Aarde SM, Creehan KM, Vandewater SA, Dickerson TJ, and Taffe MA (2015a) In vivo potency and efficacy of the novel cathinone $\alpha$-pyrrolidinopentiophenone and 3,4-methylenedioxypyrovalerone: self-administration and locomotor stimulation in male rats. Psychopharmacology (Berl) 232:3045-3055.

Aarde SM, Huang PK, Creehan KM, Dickerson TJ, and Taffe MA (2013) The novel recreational drug 3,4-methylenedioxypyrovalerone (MDPV) is a potent psychomotor stimulant: self-administration and locomotor activity in rats. Neuropharmacology 71:130-140.

Aarde SM, Huang PK, Dickerson TJ, and Taffe MA (2015b) Binge-like acquisition of 3,4-methylenedioxypyrovalerone (MDPV) self-administration and wheel activity in rats. Psychopharmacology (Berl) 232:1867-1877.

Anizan S, Concheiro M, Lehner KR, Bukhari MO, Suzuki M, Rice KC, Baumann MH, and Huestis MA (2016) Linear pharmacokinetics of 3,4-methylenedioxypyrovalerone (MDPV) and its metabolites in the rat: relationship to pharmacodynamic effects. Addict Biol 21:339-347.

Anneken JH, Angoa-Pérez M, and Kuhn DM (2015) 3,4-Methylenedioxypyrovalerone prevents while methylone enhances methamphetamine-induced damage to dopamine nerve endings: $\beta$-ketoamphetamine modulation of neurotoxicity by the dopamine transporter. $J$ Neurochem 133:211-222.

Baumann MH, Bukhari MO, Lehner KR, Anizan S, Rice KC, Concheiro M, and Huestis MA (2017) Neuropharmacology of 3,4-methylenedioxypyrovalerone (MDPV), its metabolites, and related analogs. Curr Top Behav Neurosci 32:93-117.

Baumann MH, Partilla JS, Lehner KR, Thorndike EB, Hoffman AF, Holy M, Rothman RB, Goldberg SR, Lupica CR, Sitte HH, et al. (2013) Powerful cocaine-like actions of 3,4-methylenedioxypyrovalerone (MDPV), a principal constituent of psychoactive 'bath salts' products. Neuropsychopharmacology 38:552-562.

Bolan ELIZABETH A, Kivell BRONWYN, Jaligam VANAJA, Oz MURAT, Jayanthi LANKUPALLE D, Han YANG, Sen NAMITA, Urizar ENEKI, Gomes IVONE, Devi LAKSHMI A, et al. (2007) D2 receptors regulate dopamine transporter function via an extracellular signal-regulated kinases 1 and 2-dependent and phosphoinositide 3 kinase-independent mechanism. Mol Pharmacol 71 (5):1222-1232 17267664.

Brennan KA, Colussi-Mas J, Carati C, Lea RA, Fitzmaurice PS, and Schenk S (2010) Methamphetamine self-administration and the effect of contingency on monoamine and metabolite tissue levels in the rat. Brain Res 1317:137-146.

Brown JM, Hanson GR, and Fleckenstein AE (2001) Regulation of the vesicular monoamine transporter-2: a novel mechanism for cocaine and other psychostimulants. J Pharmacol Exp Ther 296:762-767.

Callaghan RC, Cunningham JK, Sajeev G, and Kish SJ (2010) Incidence of Parkinson's disease among hospital patients with methamphetamine-use disorders. Mov Disord 25:2333-2339.

Callaghan RC, Cunningham JK, Sykes J, and Kish SJ (2012) Increased risk of Parkinson's disease in individuals hospitalized with conditions related to the use of methamphetamine or other amphetamine-type drugs. Drug Alcohol Depend 120: $35-40$.

Cameron KN, Kolanos R, Solis E Jr., Glennon RA, and De Felice LJ (2013) Bath salts components mephedrone and methylenedioxypyrovalerone (MDPV) act synergistically at the human dopamine transporter. Br J Pharmacol 168:1750-1757.

Christine CW, Garwood ER, Schrock LE, Austin DE, and McCulloch CE (2010) Parkinsonism in patients with a history of amphetamine exposure. Mov Disord 25: 228-231. 
Colon-Perez LM, Pino JA, Saha K, Pompilus M, Kaplitz S, Choudhury N, Jagnarine DA, Geste JR, Levin BA, Wilks I, et al. (2018) Functional connectivity, behavioral and dopaminergic alterations 24 hours following acute exposure to synthetic bath salt drug methylenedioxypyrovalerone. Neuropharmacology 137:178-193.

Curtin K, Fleckenstein AE, Robison RJ, Crookston MJ, Smith KR, and Hanson GR (2015) Methamphetamine/amphetamine abuse and risk of Parkinson's disease in Utah: a population-based assessment. Drug Alcohol Depend 146:30-38.

Daws LC, Callaghan PD, Morón JA, Kahlig KM, Shippenberg TS, Javitch JA, and Galli A (2002) Cocaine increases dopamine uptake and cell surface expression of dopamine transporters. Biochem Biophys Res Commun 290:1545-1550.

Dickinson S D, Sabeti J, Larson G A, Giardina K, Rubinstein M, Kelly M A, Grandy D K, Low M J, Gerhardt G A, and Zahniser N R (1999) Dopamine D2 receptordeficient mice exhibit decreased dopamine transporter function but no changes in dopamine release in dorsal striatum. J Neurochem 72 (1):148-156 9886065.

Eshleman AJ, Wolfrum KM, Hatfield MG, Johnson RA, Murphy KV, and Janowsky A (2013) Substituted methcathinones differ in transporter and receptor interactions. Biochem Pharmacol 85:1803-1815.

Farnsworth SJ, Volz TJ, Hanson GR, and Fleckenstein AE (2009) Cocaine alters vesicular dopamine sequestration and potassium-stimulated dopamine release: the role of D2 receptor activation. J Pharmacol Exp Ther 328:807-812.

Fleckenstein AE, Haughey HM, Metzger RR, Kokoshka JM, Riddle EL, Hanson JE, Gibb JW, and Hanson GR (1999) Differential effects of psychostimulants and related agents on dopaminergic and serotonergic transporter function. Eur $J$ Pharmacol 382:45-49.

Fleckenstein AE, Metzger RR, Wilkins DG, Gibb JW, and Hanson GR (1997) Rapid and reversible effects of methamphetamine on dopamine transporters. J Pharmacol Exp Ther 282:834-838.

Frankel PS, Hoonakker AJ, Alburges ME, McDougall JW, McFadden LM, Fleckenstein AE, and Hanson GR (2011) Effect of methamphetamine self-administration on neurotensin systems of the basal ganglia. J Pharmacol Exp Ther 336:809-815.

Gannon BM, Galindo KI, Rice KC, and Collins GT (2017a) Individual differences in the relative reinforcing effects of 3,4-methylenedioxypyrovalerone under fixed and progressive ratio schedules of reinforcement in rats. J Pharmacol Exp Ther 361: 181-189.

Gannon BM, Russell LN, Modi MS, Rice KC, and Fantegrossi WE (2017b) Effects of orally self-administered bath salt constituent 3,4-methylenedioxypyrovalerone (MDPV) in mice. Drug Alcohol Depend 179:408-415.

Gannon BM, Sulima A, Rice KC, and Collins GT (2018) Inhibition of cocaine and 3,4methylenedioxypyrovalerone (MDPV) self-administration by lorcaserin is mediated by 5-HT2C receptors in rats. J Pharmacol Exp Ther 364:359-366.

Garwood ER, Bekele W, McCulloch CE, and Christine CW (2006) Amphetamine exposure is elevated in Parkinson's disease. Neurotoxicology 27:1003-1006.

German CL, Hanson GR, and Fleckenstein AE (2012) Amphetamine and metham phetamine reduce striatal dopamine transporter function without concurrent dopamine transporter relocalization. J Neurochem 123:288-297.

Geste JR, Pompilus M, Febo M, and Bruijnzeel AW (2018) Self-administration of the synthetic cathinone MDPV enhances reward function via a nicotinic receptor dependent mechanism. Neuropharmacology 137:286-296.

Hadlock GC, Baucum AJ II, King JL, Horner KA, Cook GA, Gibb JW, Wilkins DG, Hanson GR, and Fleckenstein AE (2009) Mechanisms underlying methamphetamineinduced dopamine transporter complex formation. $J$ Pharmacol Exp Ther 329 169-174.

Hoffman AF, Spivak CE, and Lupica CR (2016) Enhanced dopamine release by dopamine transport inhibitors described by a restricted diffusion model and fast-scan cyclic voltammetry. ACS Chem Neurosci 7:700-709.
Johnston LD, Miech RA, O'Malley PM, Bachman JG, Schulenberg JE, and Patrick ME (2019) Monitoring the future national survey results on drug use 1975-2018: overview, key findings on adolescent drug use, Institute for Social Research, University of Michigan, Ann Arbor, MI

Lopez-Arnau R, Duart-Castells L, Aster B, Camarasa J, Escubedo E, and Pubill D (2019) Effects of MDPV on dopamine transporter regulation in male rats. Comparison with cocaine. Psychopharmacology (Berl) 236:925-938.

McFadden LM, Hadlock GC, Allen SC, Vieira-Brock PL, Stout KA, Ellis JD, Hoonakker AJ, Andrenyak DM, Nielsen SM, Wilkins DG, et al. (2012) Methamphetamine self-administration causes persistent striatal dopaminergic alterations and mitigates the deficits caused by a subsequent methamphetamine exposure. $J$ Pharmacol Exp Ther 340:295-303.

Rau KS, Birdsall E, Hanson JE, Johnson-Davis KL, Carroll FI, Wilkins DG, Gibb JW, Hanson GR, and Fleckenstein AE (2005) Bupropion increases striatal vesicular monoamine transport. Neuropharmacology 49:820-830.

Reagan-Shaw S, Nihal M, and Ahmad N (2008) Dose translation from animal to human studies revisited. FASEB $J$ 22:659-661.

Riddle EL, Topham MK, Haycock JW, Hanson GR, and Fleckenstein AE (2002) Differential trafficking of the vesicular monoamine transporter-2 by methamphetamine and cocaine. Eur J Pharmacol 449:71-74.

Ross EA, Reisfield GM, Watson MC, Chronister CW, and Goldberger BA (2012) Psychoactive "bath salts" intoxication with methylenedioxypyrovalerone. Am J Med 125:854-858.

Sandoval V, Riddle EL, Hanson GR, and Fleckenstein AE (2002) Methylphenidate redistributes vesicular monoamine transporter-2: role of dopamine receptors. J Neurosci 22:8705-8710.

Schindler CW, Thorndike EB, Goldberg SR, Lehner KR, Cozzi NV, Brandt SD, and Baumann MH (2016) Reinforcing and neurochemical effects of the "bath salts" constituents 3,4-methylenedioxypyrovalerone (MDPV) and 3,4-methylenedioxy-Nmethylcathinone (methylone) in male rats. Psychopharmacology (Berl) 233 1981-1990.

Simmler LD, Buser TA, Donzelli M, Schramm Y, Dieu LH, Huwyler J, Chaboz S, Hoener MC, and Liechti ME (2013) Pharmacological characterization of designer cathinones in vitro. Br J Pharmacol 168:458-470.

Spiller HA, Ryan ML, Weston RG, and Jansen J (2011) Clinical experience with and analytical confirmation of "bath salts" and "legal highs" (synthetic cathinones) in the United States. Clin Toxicol (Phila) 49:499-505.

Truong JG, Newman AH, Hanson GR, and Fleckenstein AE (2004) Dopamine D2 receptor activation increases vesicular dopamine uptake and redistributes vesicular monoamine transporter-2 protein. Eur J Pharmacol 504:27-32.

Vaughan RA (1995) Photoaffinity-labeled ligand binding domains on dopamine transporters identified by peptide mapping. Mol Pharmacol 47:956-964.

Volz TJ, Farnsworth SJ, Rowley SD, Hanson GR, and Fleckenstein AE (2008) Methylphenidate-induced increases in vesicular dopamine sequestration and dopamine release in the striatum: the role of muscarinic and dopamine D2 receptors. J Pharmacol Exp Ther 327:161-167.

Watterson LR, Kufahl PR, Nemirovsky NE, Sewalia K, Grabenauer M, Thomas BF, Marusich JA, Wegner S, and Olive MF (2014) Potent rewarding and reinforcing effects of the synthetic cathinone 3,4-methylenedioxypyrovalerone (MDPV). Addict Biol 19:165-174.

Address correspondence to: Dr. Annette E. Fleckenstein, University of Utah, School of Dentistry, 530 S. Wakara Way, Salt Lake City, UT 84108. E-mail: fleckenstein@hsc.utah.edu 